\title{
Evaluation of Antioxidant Activities and Phenolic Compounds of Scorzonera latifolia (Fisch. \& Mey.) DC. Collected from Different Geographic Origins in Turkey
}

\author{
Türkiye'nin Farklı Coğrafik Bölgelerinden Toplanmış Scorzonera latifolia \\ (Fisch. \& Mey.) DC. Örneklerinin Fenolik Bileşiklerinin ve Antioksidan
} Aktivitelerinin Değerlendirilmesi

\author{
Özlem Bahadır AÇIKARA ${ }^{1 *}$, Burçin ERGENE ÖZ1 , Filiz BAKAR², Gülçin SALTAN ÇiTOĞLU', Serpil NEBioĞLU² \\ 'Ankara University, Faculty of Pharmacy, Department of Pharmacognosy, Ankara, Turkey \\ ${ }^{2}$ Ankara University, Faculty of Pharmacy, Department of Biochemistry, Ankara, Turkey
}

\begin{abstract}
Objectives: The chemical composition of plants is considered to be affected by many parameters. Therefore, the region where the samples are collected is likely to have an influence on the composition of phenolic compounds, so that their biological activities. In the present study, evaluation of antioxidant activity potentials of Scorzonera latifolia (Fisch. \& Mey.) DC. aerial parts and roots, which were collected from different regions of Turkey, was aimed.

Materials and Methods: 1,1-diphenyl-2-picrylhydrazyl (DPPH) radical scavenging method and measurement of malondialdehyde (MDA) levels were used for determining antioxidant capacities of the tested extracts. In order to observe variations in the chemical composition of the investigated samples qualitatively as well as quantitatively, high performance liquid chromatography analyses were performed.

Results: Quantitative analysis showed that the amounts of chlorogenic acid and hyperoside in plants vary according to the regions where the samples were collected. As a result aerial parts of the S. latifolia collected from the Kars region have found to contain higher amount of chlorogenic acid $(1246.78 \pm 3.20 \mu \mathrm{g} / \mathrm{g})$ as well as hyperoside $(652.32 \pm 2.48 \mu \mathrm{g} / \mathrm{g})$ than other samples. The highest DPPH radical scavenging activity was determined with the $\mathrm{IC}_{50}$ value of $1.036 \mathrm{mg} / \mathrm{mL}$ for S. latifolia aerial parts of Kayseri sample. MDA level was detected as the lowest with treatment of $S$. latifolia Bayburt root sample $(4.41 \mathrm{nmol} / \mathrm{mL})$.

Conclusion: According to the antioxidant activity results, no significant difference was observed in the antioxidant potential between the samples collected from different locations except for S. latifolia collected from the Kars region.
\end{abstract}

Key words: DPPH, free radical scavenging activity, high performance liquid chromatography, MDA, Scorzonera latifolia

ÖZ

Amaç: Bitkilerin kimyasal içeriği pek çok parametreden etkilenmektedir. Bitkinin toplandığı bölge içerdiği fenolik bileșiklerin kompozisyonunu ve dolayısıyla aktivitelerini etkilemektedir. Bu çalışmada, Türkiye'nin farklı bölgelerinden toplanan Scorzonera latifolia (Fisch \& Mey.) DC. kök ve toprak üstü kısımlarının antioksidan etki potansiyallerinin ölçülmesi amaçlanmıştır.

Gereç ve Yöntemler: Test edilen ekstrelerin antioksidan kapasiteleri 1,1-difenil-2-pikrilhidrazil (DPPH) radikal süpürücü etkileri ve malondialdehit (MDA) seviyesi üzerine etkilerinin ölçülmesiyle tespit edilmiştir. Araştırma konusu olan örneklerin kimyasal içeriğindeki değişiklikleri incelemek için kalitatif ve kantitatif yüksek performanslı sıvı kromatografisi analizleri yapılmıştır.

Bulgular: Kantitatif analiz sonuçları bitkilerde tespit edilen klorojenik asit ve hiperozit miktarlarının toplandığı bölgeye göre değiștiğini göstermiştir. S. latifolia Kars örneğinin diğer örneklere göre daha yüksek hiperozit $(652.32 \pm 2.48 \mu \mathrm{g} / \mathrm{g})$ ve klorojenik asit $(1246.78 \pm 3.20 \mu \mathrm{g} / \mathrm{g})$ içeriğine sahip olduğunu ortaya koymuştur. En yüksek DPPH radikal süpürücü etki $1.036 \mathrm{mg} / \mathrm{mL}$ IC ${ }_{50}$ değeri ile S. latifolia Kayseri örneğinde gözlenmiştir. En düşük MDA seviyesi ise S. latifolia Bayburt kök örneğinde $(4.41 \mathrm{nmol} / \mathrm{mL})$ belirlenmiştir.

Sonuç: Antioksidan aktivite sonuçları değerlendirildiğinde, farklı lokasyonlardan toplanan örnekler arasında, S. latifolia Kars kök örneği haricinde belirgin bir farklılık tespit edilememiştir.

Anahtar kelimeler: DPPH, serbest radikal süpürücü aktivite, yüksek performanslı sıvı kromatografisi, MDA, Scorzonera latifolia

*Correspondence: E-mail: obahadir@ankara.edu.tr, Phone: +90 3122033103

ORCID ID: orcid.org/0000-0003-0809-784X

Received: 07.01.2016, Accepted: 26.01.2017

๑Turk J Pharm Sci, Published by Galenos Publishing House. 


\section{INTRODUCTION}

It has been reported that the risk of various chronic diseases such as cancer, diabetes, cardiovascular diseases, aging, chronic inflammation, cataracts, atherosclerosis, Alzheimer's disease could be reduced by consumption of foods and beverages rich in natural antioxidants. ${ }^{1-4}$ Although free radicals are generated by normal physiological processes and they are involved in phagocytosis, energy production and regulation of cell growth, ${ }^{5}$ exogenous factors such as smoking, pollutants, ionising radiations, alcohol, synthetic pesticides, and solvent may increase the production of free radicals. ${ }^{6}$ The overproduction of free radicals provokes oxidative damage on nucleic acids, proteins, lipids or DNA and causes degenerative diseases. ${ }^{7}$ Natural antioxidants provide protection by their inhibitor and scavenger activities on free radicals. ${ }^{4}$ Therefore, the plants containing natural antioxidants are considered to have therapeutic potential in treatment of many diseases and these findings have led to increased interest in the antioxidant activity studies of plants. ${ }^{1-3}$

Vitamin C, Vitamin E, carotenoids and phenolic compounds are recognized as the natural antioxidants found in plants. ${ }^{8}$ The phenolic compounds consisting of flavonoids, isoflavones, flavones, anthocyanins, coumarins, lignans, catechins and isocatechins, etc. ${ }^{9}$ have been shown to possess strong antioxidant activity. ${ }^{5}$ Phenolic compounds exert their antioxidant activities mainly due to their redox properties that led to act them as reducing agents, hydrogen donors, singlet oxygen quenchers or metal chelators. ${ }^{10,11}$ Different parameters such as time and period of sample collection, geographical origin and climatic conditions are considered as notable factors influencing the phenolic composition of plants. ${ }^{11,12}$ The plants, cultivated with different conditions, exhibit an alteration in the quantity of phytochemicals and therefore display varied therapeutic effects.13,14 The quality, uniformity and quantity of chemical constituents in plants are important parameters for the safety and effectiveness of herbal drugs. ${ }^{14}$ The genus Scorzonera L. which consists of about 180 species belongs to Asteraceae family and is distributed in arid regions of Asia, Europe and Africa. It is represented by 50 species in Turkey. ${ }^{15}$ The members of this genus are used as folk remedies against several diseases such as arteriosclerosis, kidney problems, hypertension and also for wound healing. 16,17 Scorzonera latifolia Fisc. \& Mey. (Asteraceae) naturally grows in Central and East Anatolian Region and it is a widely known species from which a mastic named "yakı sakızı" is obtained. Yakı sakızı is known to be prepared from the latex of the plant roots and used as a folk medicine for its analgesic activity and against infertility externally as well as antihelmintic internally. ${ }^{17}$ Antinociceptive, anti-inflammatory, wound healing, antioxidant and antimicrobial activities of S. latifolia have been reported. ${ }^{18-21}$ S. latifolia roots contain terpenes; taraxasteryl myristate, taraxasteryl acetate, motiol, 3- $\beta$ - hydroxy fern-8 en-7-one acetate, urs-12-en-11-one3-acetyl, 3- $\beta$-hydroxy-fern-7-en-6-one-acetate, olean-12-en11-one-3-acetyl, fern-7-en-3- $\beta$-one, leucodin, $\beta$-sitosterol ${ }^{22-24}$, phenolic compounds; chlorogenic acid, chlorogenic acid methyl ester, 1,5-dicaffeoyl quinic acid, 3,5-dicaffeoyl quinic acid, methylester of 3,5-dicaffeoyl quinic acid, hydrangenol-8-Oglucoside, hydrangenol-4'-O-glucoside, scorzotomentosin$4^{\prime}$-O-glucoside and a new isocoumarine derivative ${ }^{25}$ as well as scorzoveratrin 4'-O- $\beta$-glucoside, scorzoveratrin, scorzoveratrozit, 4,5-dicaffeoylquinic acid, 4,5-dicaffeoylquinic acid methyl ester and caffeic acid. ${ }^{26}$ Aerial parts of the plant have been reported to contain phenolics which were identified as quercetin-3-O- $\beta$-glucoside, hyperoside, hydrangenol-8-Oglucoside, swertisin, 7-methylisoorientin, 4,5-O-dicaffeoylquinic acid, 3,5-di-O-caffeoyl-quinic acid and chlorogenic acid. $^{27}$

In the current study, three samples of S. latifolia Fisc. \& Mey. which were collected randomly from different locations of Turkey were evaluated for their antioxidant capacities and we also observed qualitative and quantitative variations in the chemical composition of samples by HPLC analysis.

\section{EXPERIMENTAL}

\section{Plant materials}

S. latifolia samples were collected from different locations of Turkey in flowering period. Identification of these plants was confirmed by Prof. Dr. H. Duman, in the Department of Biological Sciences, Faculty of Art and Sciences, Gazi University. Voucher specimens were stored in the herbarium of Ankara University, Faculty of Pharmacy (AEF) (Table 1).

\section{Preparation of the extracts}

Dried and powdered roots and aerial parts of the plants $(0.25$ $\mathrm{g}$, each) were extracted in $10 \mathrm{~mL}$ of methanol:water (80:20) mixture by continuous stirring at room temperature for 8 hours. Obtained extracts were filtered and then concentrated to dryness under reduced pressure and low temperature $\left(40-50^{\circ} \mathrm{C}\right)$ on a rotary evaporator to give crude extracts. The crude extracts were dissolved in methanol-water mixture and adjusted to $10 \mathrm{~mL}$ in volumetric flask.

\section{Phytochemical screening}

\section{HPLC analysis}

For the HPLC analyses of the extracts of the roots and aerial parts of Scorzonera species, the method which was developed and validated by Küpeli Akkol et al. ${ }^{19}$ was used. In accordance with this method, the analyses were carried out using Agilent LC 1100 model cromatograph (Agilent Technologies, California,

Table 1. Collection sites and herbarium numbers of the plants

\begin{tabular}{llc} 
Plant species & Locality & AEF no \\
\hline S. latifolia (Kars) & $\begin{array}{l}\text { Kars, Arpaçay, between } \\
\text { Telekköy and Melekköy }\end{array}$ & 23830 \\
\hline S. latifolia (Kayseri) & $\begin{array}{l}\text { Kayseri, Erciyes Mountain, } \\
1800-2000 \mathrm{~m}\end{array}$ & 25941 \\
\hline S. latifolia (Bayburt) & $\begin{array}{l}\text { Bayburt, Kop Passage, 2000- } \\
2409 \mathrm{~m}\end{array}$ & 23827 \\
\hline
\end{tabular}


USA) at the wavelength of $254 \mathrm{~nm}$ and peak areas were integrated by Agilent Software. A Supelcosil $(250 \mathrm{~mm} \times 4.6 \mathrm{~mm}$; $5 \mu \mathrm{m}$ ) column was used with a gradient elution of acetonitrile (A) and water: $0 \mathrm{~min}, \mathrm{~A}-\mathrm{B}(8: 92, \mathrm{v} / \mathrm{v}) ; 0-10 \mathrm{~min}$, linear change from $A-B(8: 92, v / v)$ to $A-B(18: 82) ; 10-20 \mathrm{~min}$, a linear change from $A-B(18: 82)$ to $A-B(20: 80) ; 20-30$ min, a linear gradient elution from A-B (20:80) to A-B (30:70). Phenolic acids including $p$-coumaric acid, ferulic acid, rosmarinic acid, caffeic acid, chlorogenic acid and flavonoids such as apigenin, luteolin, quercetin, rutin, hyperoside, hesperidin were used as standards.

\section{$D P P H$ radical scavenging activity}

$\mathrm{DPPH}$ radical scavenging activity assays of the samples were carried out according to the method of Williams et al. ${ }^{28} 0.01$ $\mathrm{g}$ of sample was dissolved in $10 \mathrm{~mL}$ dimethylsulfoxide and seven different concentrations ( $1 \mathrm{mg} / \mathrm{mL}$ to $0.015 \mathrm{mg} / \mathrm{mL}$ ) were prepared with $1 / 2$ dilutions. $2.9 \mathrm{~mL}$ DPPH solution dissolved in $10^{-4} \mathrm{M}$ ethanol was added into $0.1 \mathrm{~mL}$ of sample solutions. The mixture was shaken vigorously and incubated $30 \mathrm{~min}$ in a water bath adjusted to $30^{\circ} \mathrm{C}$. Absorbance of the resulting solution was measured against the blank (the same mixture without the sample) at $517 \mathrm{~nm}$ UV-visible spectrophotometer (Shimadzu). All assays were carried out in triplicates and propylgallate is used as positive control. Percentage of inhibition determined as follows:

$\%$ DPPH radical-scavenging $=[$ (Absorbance of control Absorbance of sample) / Absorbance of control] $\times 100$

According to this method, decrease at the absorbance of the reaction mixture indicates stronger DPPH radical-scavenging activity. For each sample, the $I_{50}$ values were calculated by linear regression analysis using \% inhibition and concentration values.

\section{Thiobarbituric acid reactive substances assay}

The measurement of malondialdehyde (MDA) levels was performed spectrophotometrically according to the modified method of Puhl et al. ${ }^{29}$ and Zhang et al. ${ }^{30} 2.0 \mathrm{mg}$ of plant extracts solved in $\mathrm{dH}_{2} \mathrm{O}$ were incubated with $8.125 \mathrm{mM} \mathrm{CuSO}_{4}$ solution. Following incubation, trichloroacetic acid $(0.1 \mathrm{~g} /$ $\mathrm{dL}$, final volume) and thiobarbituric acid (TBA) $(0.67 \mathrm{~g} / \mathrm{dL}$, final volume) solutions were added and the absorbance was measured at $532 \mathrm{~nm}$. Quantitation of TBA reactive substances (TBARS) was performed by comparison with a standard curve of MDA equivalents generated by acid-catalyzed hydrolysis of 1,1,3,3-tetraethoxypropane and the results were expressed as $\mathrm{nmol} / \mathrm{mL}$.

\section{RESULTS AND DISCUSSION}

Natural antioxidants from plant sources have been gaining more interest in recent years due to their important roles in the maintenance of health and protection from ageing-related degenerative diseases. ${ }^{31,32}$ Plants serve as potential sources of compounds with antioxidant activity such as vitamin C, vitamin E, carotenoids, phenolic compounds, etc. ${ }^{33}$ Phenolic compounds, one of the largest group of secondary metabolites, exhibit strong antioxidant activity as free radical scavengers, hydrogen donating sources or as singlet oxygen quenchers and metal ion chelators. 10,31

In the current study, antioxidant activities of S. latifolia samples were evaluated by using two different methods. The DPPH method is the most common, cost-effective and quick method to evaluate antioxidant activities of natural products. ${ }^{33,34}$ Scavenging activity against DPPH radical is considered as hydrogen donating ability of samples. DPPH is a stable free radical and accepts an electron on hydrogen radical to become a stable diamagnetic molecule. ${ }^{33}$ The DPPH is decolorized by accepting an electron donated by an antioxidant. ${ }^{12}$ DPPH radical scavenging activities of extracts are presented in Table 2. Among the root samples, S. latifolia Kars sample showed the highest DPPH radical scavenging activity with the $I_{50}$ value of $1.906 \mathrm{mg} / \mathrm{mL}$ as the highest activity among the tested aerial parts was determined for S. latifolia Kayseri sample $\left(I C_{50}=1.036 \mathrm{mg} / \mathrm{mL}\right)$.

Lipid oxidation plays an important role in the generation of reactive oxygen species and is considered as an important factor in the initiation and progression of several diseases. ${ }^{35}$ TBARS assay is used to measure the degree of lipid peroxidation. TBA reacts with MDA which is a secondary product of lipid peroxidation, to give a red chromogen, than can be determined spectrophotometrically. ${ }^{36}$ In the TBARS assay, the MDA levels for the root of $S$. latifolia samples from Bayburt, Kayseri, and Kars were determined as $4.41 \mathrm{nmol} / \mathrm{mL}, 4.66 \mathrm{nmol} / \mathrm{mL}$, and 5.41 $\mathrm{nmol} / \mathrm{mL}$, respectively (Table 3 ).

The extracts of the aerial parts of all S. latifolia samples inhibited lipid peroxidation significantly and the lowest MDA level was detected in Kayseri sample as $5.15 \mathrm{nmol} / \mathrm{mL}$ (Table 3).

\begin{tabular}{lcl}
\multicolumn{2}{l}{$\begin{array}{l}\text { Table 2. IC } \\
\text { scavenging assay }\end{array}$ Ralues $(\mathrm{mg} / \mathrm{mL})$ of plant extracts in DPPH radical } \\
Plant material & Root & Aerial parts \\
\hline S. latifolia (Kars) & 1.906 & 1.122 \\
\hline S. latifolia (Kayseri) & 4.102 & 1.036 \\
S. latifolia (Bayburt) & 4.628 & 1.143 \\
\hline & Control & \\
\hline Propylgallate & 0.742 & \\
\hline
\end{tabular}

DPPH: 1,1-difenil-2-pikrilhidrazil

Table 3. MDA levels of plant extracts, the results are given as $\mathrm{nmol} / \mathrm{mL}$ concentrations

\begin{tabular}{lll} 
Plant material & Root & Aerial parts \\
\hline S. latifolia (Kars) & 5.41 & 6.14 \\
\hline S. latifolia (Kayseri) & 4.66 & 5.15 \\
\hline S. latifolia (Bayburt) & 4.41 & 5.90 \\
\hline
\end{tabular}

MDA: Malondialdehit 
The radical scavenging activities of the extracts were not found to be quite different except S. latifolia root Kars sample. Aerial part samples exhibited higher scavenger activities on DPPH radical compared to root samples (Table 2). The observed scavenger activities of aerial part samples were also close to the effect of propylgallate which is the positive control of the assay.

According to the HPLC results, root samples contain chlorogenic acid as one of the major constituent both in roots (Figure 1) and aerial parts (Figure 2) of S. latifolia. The highest amount was detected in the root of Kars sample as $1246.78 \pm 3.20 \mu \mathrm{g} / \mathrm{g}$. None of the tested flavonoid standards were detected in root samples (Figure 3). However all aerial part samples contain chlorogenic acid as well as hyperoside as major compounds. Aerial part of $S$. latifolia was also found to contain higher amount of chlorogenic acid $(652.32 \pm 2.48 \mu \mathrm{g} / \mathrm{g})$ as well as hyperoside $(305.71 \pm 1.70$ $\mu \mathrm{g} / \mathrm{g}$ ) (Table 4).

Differences between the scavenging activity of root and aerial part extracts on DPPH radical may be explained by the flavonoid content of aerial part samples. It has been reported that, flavonoids which are widely distributed in plants have the ability to scavenge active oxygen radicals, superoxide and hydroxyl radicals by single electron transfer. ${ }^{37}$ On the other hand in the TBARS assay, root samples were found to be more active when

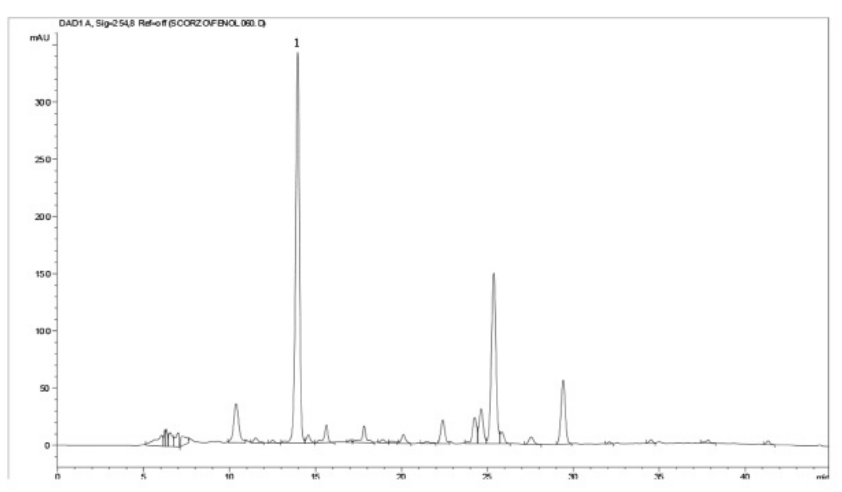

Figure 1. Chromatogram of the S. latifolia root (Kars sample) extract 1: Chlorogenic acid

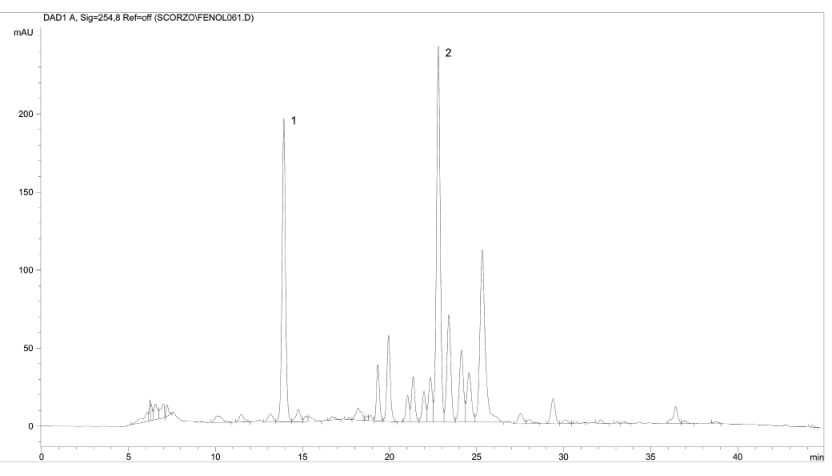

Figure 2. Chromatogram of the S. latifolia aerial part (Kars sample) extract 1: Chlorogenic acid, 2: Hyperoside compared to aerial part samples. These results may be related to high amount of chlorogenic acid content of root extracts. Chlorogenic acid exhibits scavenging activity against reactive oxygen and nitrogen species ${ }^{38}$ and inhibits the initiation of chain lipid peroxidations by free radicals. ${ }^{39}$ Antioxidant activity of chlorogenic acid (5-CQA) against human LDL has also been reported. ${ }^{36}$ Thus, chlorogenic acid may be considered to be one of the responsible compounds for the antioxidant activities of S. latifolia samples.

Qualitative and quantitative changes in the phytochemical composition of the S. latifolia root and aerial part samples which were collected from different localities of Anatolia were investigated by HPLC in the current study and the differences between the amounts of chlorogenic acid and hyperoside were observed. Results of present study have revealed that different samples of S. latifolia root and aerial parts have similar chemical composition however the quantity of the chlorogenic acid and hyperoside were different. A number of factors such as temperature, season, stages of maturity, geographical origin, climatic conditions and soil may affect the phytochemical content of plants. ${ }^{11,12,40,41}$ Changes in the phytochemical composition may result variation in therapeutic effects of the medicinal plants. ${ }^{13,14}$ According to the antioxidant activity results; we didn't find a significant correlation between the chlorogenic acid and/or hyperoside content and antioxidant capacities of samples.

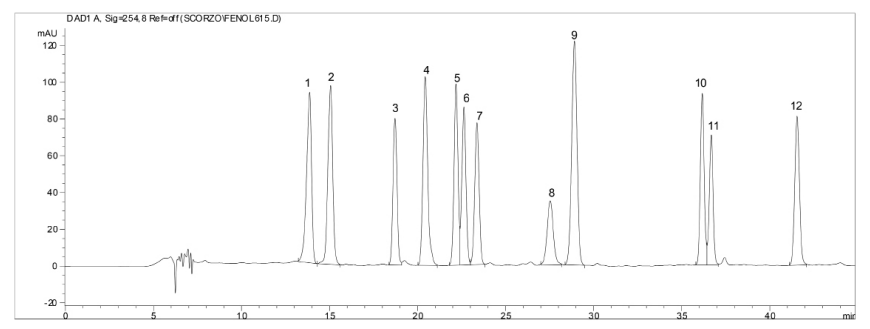

Figure 3. Chromatogram of the standart mixture

1: Chlorogenic acid, 2: Caffeic acid, 3: $p$-Coumaric acid, 4: Ferulic acid, 5: Rutin, 6: Hyperoside, 7: Luteolin-7-glucoside, 8: Hesperidin, 9: Rosmarinic acid, 10: Quercetin, 11: Luteolin, 12: Apigenin

Table 4. HPLC qualitative and quantitative data for roots and aerial parts of Scorzonera samples $(\mu \mathrm{g} / \mathrm{g})$

\begin{tabular}{llll} 
Plant material & \multicolumn{1}{c}{$\begin{array}{l}\text { Chlorogenic acid } \\
(\mu \mathrm{g} / \mathrm{g} \pm \text { standart } \\
\text { error })\end{array}$} & $\begin{array}{l}\text { Hyperoside } \\
(\mu \mathrm{g} / \mathrm{g} \pm \text { standart } \\
\text { error })\end{array}$ \\
\hline S. latifolia (Kars) & $\mathrm{R}^{*}$ & $1246.78 \pm 3.20$ & - \\
\cline { 2 - 4 } & $\mathrm{AE}^{*}$ & $652.32 \pm 2.48$ & $305.71 \pm 1.70$ \\
\hline S. latifolia (Kayseri) & $\mathrm{R}^{*}$ & $988.070 \pm 3.78$ & - \\
\cline { 2 - 4 } & $\mathrm{AE}^{*}$ & $290.64 \pm 0.84$ & $70.99 \pm 0.29$ \\
\hline S. latifolia (Bayburt) & $\mathrm{R}^{*}$ & $541.96 \pm 2.56$ & - \\
\cline { 2 - 4 } & $\mathrm{AE}^{*}$ & $295.27 \pm 0.53$ & $36.24 \pm 0.42$ \\
\hline
\end{tabular}

*R: Root, *AE: Aerial part 


\section{CONCLUSION}

In conclusion, quantitative analyses have shown that same species collected from different localities may have different chemical composition. Therefore, the region chosen for the collection of a plant which is used as an herbal remedy is a very important parameter with respect to the effectiveness of an herbal drug.

Conflict of Interest: No conflict of interest was declared by the authors.

\section{REFERENCES}

1. Choi E, Hwang JK, Antiinflammatory, analgesic and antioxidant activities of the fruit of Foeniculum vulgare. Fitoterapia. 2004;75:557565.

2. Gonçalves C, Dinis T, Batista MT. Antioxidant properties of proanthocyanidins of Uncaria tomentosa bark decoction: a mechanism for anti-inflammatory activity. Phytochemistry. 2005;66:89-98.

3. Conforti F, Sosa S, Marrelli M, Menichini F, Statti GA, Uzunov D, Tubaro A, Menichini F, Loggia RD. In vivo anti-inflammatory and in vitro antioxidant activities of Mediterranean dietary plants. J Ethnopharmacol. 2008;116:144-151.

4. Guha G, Rajkumar V, Mathew L, Kumar RA. The antioxidant and DNA protection potential of Indian tribal medicinal plants. Turk J Biol. 2011;35:233-242.

5. Narayanaswamy N, Balakrishnan KP. Evaluation of some medicinal plants for their antioxidant properties. Int J Pharm Tech Res. 2011;3:381385.

6. Amiri H. Essential oils composition and antioxidant properties of three thymus species. Evid Based Complement Alternat Med. 2012;2012:728065

7. Parakash A, Rigelhof F, Miller E, Antioxidant activity, Medallion Laboratories Analytical Progress. http://www.medlabs.com/ Downloads/Antiox_acti_.pdf

8. Ara N, Nur H. In vitro antioxidant activity of methanolic leaves and flowers exracts of Lippia alba. Res J Med Sci. 2009;4:107-110.

9. Michalak A. Phenolic compounds and their antioxidant activity in plants growing under heavy metal stress. Polish J Environ Stud. 2006;15:523530.

10. Teixeire EW, Message D, Negri G, Salatino A, Stringheta PC. Seasonal variation, chemical composition and antioxidant activity of Brazilian Propolis samples. Evid Based Complement Alternat Med. 2010;7:307315.

11. Banerjee SK, Bonde CG. Total phenolic content and antioxidant activity of extracts of Bridelia retusa Spreng bark: Impact of dielectric constant and geographical location. J Med Plants Res. 2011;5:817-822.

12. Gull J, Sultana B, Anwar F, Naseer R, Ashraf M, Ashrafuzzaman M. Variation in antioxidant attributes at three ripening stages of guava (Psidium guajava L.) fruit from different geographical region of Pakistan. Molecules. 2012;17:3165-3180.

13. Sun YF, Liang ZS, Shan CJ, Viernstein H, Unger F. Comprehensive evaluation of natural antioxidants and antioxidant potentials in Ziziphus jujube Mill. var. spinosa (Bunge) Hu ex H.F. Chou fruits based on geographical origin by TOPSIS method. Food Chem. 2011;124:1612-1619.
14. Kolawole OT, Ayankunle AA. Seasonal variation in the anti-diabetic and hypolipidemic effects of Momordica charantia fruit extract in rats. European J Med Plants. 2012;2:177-185.

15. Duran A, Dogan B, Hamzaoglu E, Aksoy A. Scorzonera coriacea A. Duran \& Aksoy (Asteraceae, Cichorieae), a new species from South Anatolia, Turkey. Candollea. 2011;62:353-359.

16. Sezik E, Yeșilada E, Tabata M, Honda G, Takaishi Y, Fujita T, Tanaka T, Takeda Y. Traditional medicine in Turkey VIII. Folk medicine in East Anatolia; Erzurum, Erzincan, Ağrı, Kars, Iğdır provinces, Econ Bot. 1997;51:195-211.

17. Baytop T. Therapy with medicinal plants in Turkey-past and present Ankara, Turkey, Nobel Publishers, 1999.

18. Sarı A, Özbek B, Özgökçe F, Antimicrobial activities of two Scorzonera species growing in Turkey, Asian J Chem. 2009;21:4785-4788.

19. Küpeli Akkol E, Acıkara OB, Süntar I, Citoglu GS, Keleş H, Ergene B. Enhancement of wound healing by topical application of Scorzonera species: Determination of the constituents by HPLC with new validated reverse phase method. J Ethnopharmacol. 2011;137:1018-1027.

20. Bahadır Ö, Saltan HG, Özbek H, Antinociceptive activity of some Scorzonera L. Species. Turk J Med Sci. 2012;42:861-866.

21. Erden Y, Kırbağ S, Yılmaz Ö. Phytochemical composition and antioxidant activity of some Scorzonera species. Proc Natl Acad Sci India Sect B Biol Sci. 2013;83:271-276.

22. Bahadir O, Citoğlu GS, Smejkal K, Dall'Acqua S, Ozbek H, Cvacka J, Zemlicka M. Analgesic compounds from Scorzonera latifolia (Fisch. and Mey.) DC. J Ethnopharmacol. 2010;131:83-87.

23. Acıkara ÖB, Çitoğlu GS, Dall'Acqua S, Smejkal K, Cvačka J, Zemlička M, A new triterpene from Scorzonera latifolia (Fisch. and Mey.) DC. Nat Prod Res. 2012;26:1892-1897.

24. Acikara OB, Citoğlu GS, Dall'Acqua S, Ozbek H, Cvacka J, Zemlicka M, Smejkal K. Bioassay-guided isolation of the antinociceptive compounds motiol and $\beta$-sitosterol from Scorzonera latifolia root extract. Pharmazie. 2014:69:711-714.

25. Bahadır Acıkara Ö, Smejkal K, Cvacka J, Budesinsky M, Dracinsky M, Saltan G. Secondary metabolites from Scorzonera latifolia roots. Planta Med. 2015;81:167.

26. Sarı A. Phenolic compounds from Scorzonera latifolia (Fisch. \& Mey.) DC. Nat Prod Res. 2012;26:50-55.

27. Bahadır Acikara Ö, Hošek J, Babula P, Cvačka J, Budešínský M, Dračinský M, Saltan İşcan G, Kadlecová D, Ballová L, Šmejkal K. Turkish Scorzonera species extracts attenuate cytokine secretion via inhibition of NF- $\mathrm{KB}$ activation, showing anti-inflammatory effect in vitro. Molecules. 2015;21:43.

28. Williams WB, Cuvelier ME, Berset C. Use of free radical method to evaluate antioxidant activity. Food Sci Technol. 1995;28:25-30.

29. Puhl $\mathrm{H}$, Waeg G, Esterbauer $\mathrm{H}$. Methods to determine oxidation of low density lipoproteins. Method Enzymol. 1994;233:425-441.

30. Zhang A, Vertommen J, Van Gaal L, De Leeuw I. A rapid and simple method for measuring the susceptibility of low density lipoprotein and very low density lipoprotein to copper catalyzed oxidation. Clin Chim Acta. 1994;227:159-173.

31. Hsu CY, Chan YP, Chang J. Antioxidant activity of extract from Polygonum cuspidatum. Biol Res. 2007;40:13-21. 
32. Charde MS, Shukla A, Bukhariya V, Chakole JMR. Herbal remedies as antioxidants: An overview. International Journal of Pharmacological Research. 2011;1:25-34.

33. Arulmozhi S, Mazumder PM, Narayanan LS, Thakurdesai PA. In vitro antioxidant and free radical scavenging activity of Alstonia scholaris Linn. R. Br. Int J PharmTech Res. 2007;6:191-196.

34. Singh DR, Singh S, Salim KM, Srivastava RC. Estimation of phytochemicals and antioxidant activity of underutilized fruits of Andaman Islands (India). Int J Food Sci Nutr. 2012;63:446-452.

35. Waqar MA, Mohmood Y. Anti- platelet, anti-hypercholesterolemic and anti-oxidant effects of ethanolic extracts of Brassica oleracea in high fat diet provided rats. World Appl Sci J. 2010;8:107-112.

36. Lakshmi A, Arawwawala LDA, Nandakumara A. Antioxidant and antifungal activities of essential oil of Alpinia calcarata Roscoe rhizomes. J Ayurveda Integr Med. 2012;3:199-202.
37. Chu YH, Chang CL, Hsu HF. Flavonoid content of several vegetables and their antioxidant activity. J Sci Food Agric. 2000;80:561-566.

38. Nakatani N, Kayano S, Kikuzaki, Sumino K, Katagiri K, Mitani T. Identification, quantitative determination and antioxidative activities of chlorogenic acid isomers in prune (Prunus domestica L). J Agric Food Chem. 2000;48:5512-5516.

39. Kono Y, Kobayashi K, Tagawa S, Adachi K, Ueda A, Sawa Y, Shibata $H$. Antioxidant activity of polyphenolics in diets. Rate constants of reactions of chlorogenic acid and caffeic acid with recative species of oxygen and nitrogen. Biochim Biophys Acta. 1997;1335:335-342.

40. Carmona JR, Yousef GG, Martinez-Peniche RA, Lila MA. Antioxidant capacity of fruit extracts of blackberry (Rubus sp.) produced in different climatic regions. J Food Sci. 2005;70:497-503.

41. Uzelac VD, Levaj B, Mrkic V, Bursac D, Boras M. The content of polyphenols and carotenoids in three apricot cultivars depending on stage of maturity and geographical region. Food Chem. 2007;102:966-975. 